\title{
Why This Time Is Different for Ukraine
}

The Ukrainian government has committed to implement far-reaching reforms in exchange for the support it is getting from the international community, led by the International Monetary Fund (IMF). Understandably, given Ukraine's disappointing transition history, there is widespread scepticism on whether the country will live up to its commitments. Three failed IMF programmes later, the fundamental question is: Is it different this time?

The odds are very much against the new government and its reform efforts. It is fighting a war on at least two fronts - against a deeply entrenched oligarchy and against a hostile neighbour. Add to this an economy in deep decline. The banking sector is being cleaned up, but overall financial stability is still an issue after the massive depreciation of the hryvnia, the Ukrainian currency. The economic environment is hardly cooperative, with a contracting Russian economy increasingly closed off for Ukrainian exports and tepid growth in the rest of Europe. International financial support has been slow in coming, and amounts are small compared to needs. To make ends meet, the government is now restructuring its debt in negotiations with creditors.

There are essentially two views on whether the prospects for real reforms are different this time. One emphasises that, despite the overthrow of a thoroughly crooked president and the disintegration of his party of cronies, Ukraine remains the most corrupt country in Europe. The political process has been captured by oligarchs, some with their own private armies and control over large land areas and most of the government apparatus. According to another, more benign, account, Ukraine is a country cleansed by a rebellion and with a new government of young noncorrupt professionals determined to transform their country into a European democracy. Both these views have some truth to them - one emphasises the legacy of the past and the other the promise of the future - and it is not easy to discern which one describes the current state of affairs most correctly and is certainly too early to tell which one will win out in the end. But one thing is clear: the political and economic framework for policymaking has changed dramatically over the last year. It is worthwhile to describe this new reform architecture in some detail in order to understand what has been achieved.

To start with, one year ago Ukraine did not have an elected president, nor a representative and functioning parliament which could elect a legitimate government. The political landscape was deeply fragmented and, while civil society had been energised by the Maidan rebellion, it was in turmoil. The EU association agreement had helped spark the revolution but also left the country deeply divided. Civil society organisations were asking for complete lustration of government organs and the judiciary.

Since then national identity has strengthened, as has support for a European orientation, in large part fuelled by the Russian intervention. Opinion polls show that people, even in the occupied territories, are more favourable towards the EU today than they were a year ago. It is true that large parts of the east voted differently from the rest of the country in the parliamentary elections, but the overwhelming majority came out in favour of Europe. They also said "no" to nationalism, leaving the right-wing extremist parties without representation. A completely new party, the Self-Help Party, made its way into the parliament, the Rada, and the five-party government coalition.

The seemingly fragile government coalition of five parties has held up remarkably well. Yes, there are worrying populist tendencies from some of its members, but an analysis of voting patterns in the parliament shows that so far the coalition representatives overwhelmingly vote together, even on very difficult issues. The government has, among other things, raised gas tariffs by 450 per cent (from absurdly low levels). Yet, dissension has been relatively moderate. 
The country's core institutions are now undergoing fundamental change. The central bank, once a pocket bank for the oligarchs and a supplier of insider information on exchange rate movements in exchange for bribes, is being reformed from the top with a governor committed to change and surrounded by an increasingly professional team. The energy monopoly Naftagaz, previously an opaque cesspool of illicit transactions, has in a year managed the seemingly impossible task of making Ukraine independent from direct gas delivery from Russia, at least for this year, helped by falling demand, particulary from the energy-intensive eastern parts of the country, and by allowing for reflows from other countries, importing Norwegian gas and cleverly exploiting idle infrastructure.

Probably the single most important achievement is the establishment of the National Reform Council (NRC), a government entity initially set up by the presidential administration, but now governed in conjunction with representatives from the cabinet and the Rada; civil society is also represented. Originally set up to coordinate reforms across ministries and monitor the implementation of reforms, it has come to serve as an important tool to discuss and ensure coherence among the different branches of government. The NRC meets every three weeks with President Petro Poroshenko as well as Prime Minister Arseniy Yatsenyuk and his entire cabinet.

In between NRC meetings, a special project management office is supporting the preparation and implementation of key reforms by ministries. Thanks to support from the European Bank for Reconstruction and Development, the George Soros-funded International Renaissance Foundation (IRF) and the Swedish government, among others, the project management office can hire staff at market rates, raising the quality of the government administration. The main engine behind the NRC, Dmytro Shymkiv, the first deputy head of the presidential administration, was previously CEO of Microsoft Ukraine. A number of task forces, funded by the IRF, are providing the NRC with useful expert advice across a wide range of policy areas.

Individual ministers are taking charge, with the finance minister Natalie Jaresko, the minister of economy Aivaras Abramovicius and infrastructure minister Andriy Pivovarsky playing key roles in pushing the reform agenda forward. Like Shymkiv, all of them come from the private sector, and Jaresko and Abramovicius were actually not even Ukrainian citizens when they joined the government. They work for salaries which are orders of magnitudes smaller than what they earned previously, and they even employ some staff using their own money. Quite a few in the government apparatus are also volunteers. Finding more sustainable arrangements is a key priority.

The ambitious agendas of the government ministers and the presidential administration are closely monitored by a civil society which has been dramatically radicalised following the events in Maidan last year. As George Soros has noted, Ukraine probably has the most energetic civil society in Europe at the moment. These organisations have mushroomed over the last year and a half and draw heavily on deeply committed individuals working without pay. A number of representatives of civil society have also joined the Rada, particularly on the platform of the Self-Help Party, but other parties have also absorbed civil society activists. One of the most interesting new civil society institutions is the web-based network VoxUkraine, which is determined to change the way the political process works. Initiated by two Ukrainian economics professors based in the US, Yuri Gorodnichenko and Timofiy Mylovanov, they were later joined by a group of locally based economists. Together they have championed modern evidence-based decision-making and constantly come up with new constructive ways of challenging the government and its assumptions.

Erik Berglof, London School of Economics, UK.
The battle over the future of reform in Ukraine is far from won, but real progress has been made. For the first time since the transition started, Ukraine has a machinery in place that can support reform and a clear sense of direction. Momentum can be sustained by a stronger sense of national identity, and additional fuel comes from an energised civil society. Even if a true truce with Russia and the separatists seems elusive, there are signs that the grip of the oligarchs is loosening, in part due to internal conflicts among them. For Ukraine, this time is different. 